\title{
Determinan Kepatuhan dan Penerimaan PPh Badan Pada Kantor Wilayah Direktorat Jenderal Pajak Jakarta Timur
}

\author{
Wieldy Menanda1, Darmansyah², JMV. Mulyadi ${ }^{3}$ \\ 1,2,3,4 Universitas Pancasila, Jakarta, Indonesia
}

\section{INFO ARTIKEL \\ JEL Classification :}

H20, H32

\section{Keywords :}

corporate income tax revenue, socialization of tax policies, supervision of taxpayers, tax audits, tax collection, tax payer compliance

\begin{abstract}
Taxpayer compliance is the most important part of tax revenue. In compliance there is formal and material compliance. Formal compliance is the compliance of taxpayers in depositing and reporting their tax obligations on time, while material compliance is compliance with the correctness of the contents of the reporting itself in the form of income received, costs incurred, taxes withheld / collected by other parties, up to taxes that still have to be paid. after carrying out various conversion mechanisms according to the applicable regulations. This research aims to determine how the relationship between tax policy socialization, taxpayer supervision, tax audit and tax collection on taxpayer compliance and corporate income tax receipts when mediated by taxpayer compliance. In this study, secondary data sources were taken from 9 (nine) Tax Service Offices (KPP) in the East Jakarta Regional Tax Office. In the form of target and realization data for the period 2014 to 2018 on 4 (four) activity instruments (socialization, supervision, inspection and collection) carried out at the Directorate General of Taxes. The results showed that tax policy socialization and taxpayer supervision had a significant effect on compliance, while tax audit and tax collection had no significant effect. For the effect on corporate income tax revenue through taxpayer compliance, tax policy socialization, taxpayer supervision has a significant negative effect, while tax audit and tax collection have a significant positive effect. For researchers who want to take the same theme as this research, they can develop it with the addition of independent variables and a longer research year in order to obtain results that better reflect the actual conditions.
\end{abstract}

\begin{abstract}
ABSTRAK
Kepatuhan wajib pajak merupakan bagian terpenting dalam penerimaan pajak. Didalam kepatuhan terdapat kepatuhan formal dan material. Kepatuhan formal merupakan kepatuhan wajib pajak dalam menyetorkan dan melaporkan kewajiban perpajakannya tepat waktu sedangkan kepatuhan material adalah kepatuhan terkait kebenaran isi dari pelaporan itu sendiri berupa penghasilan yang diterima, biaya yang dikeluarkan, pajak yang dipotong/dipungut oleh pihak lain sampai dengan pajak yang masih harus dibayarkan setelah dilakukan berbagai mekanisme konversi sesuai aturan yang berlaku. Riset ini bertujuan untuk mengetahui bagaimana hubungan sosialisasi
\end{abstract}


kebijakan pajak, pengawasan wajib pajak, pemeriksaan pajak Dalam penelitian ini sumber data sekunder diambildari 9 (sembilan) Kantor Pelayanan Pajak (KPP) di lingkungan Kantor Wilayah DJP Jakarta Timur. Berupa data target dan realisasi selama periode 2014 sampai dengan 2018 atas 4 (empat) instrumen kegiatan (sosialisasi, pengawasan, pemeriksaan dan penagihan) yang dilakukan di Direktorat Jenderal Pajak. Hasil penelitian menunjukkan sosialisasi kebijakan pajak dan pengawasan wajib pajak berpengaruh signifikan terhadap kepatuhan sedangkan pemeriksaan pajak dan penagihan pajak tidak berpengaruh signifikan. Untuk pengaruh terhadap penerimaan PPh Badan melalui kepatuhan wajib pajak, sosialisasi kebijakan pajak, pengawasan wajib pajak berpengaruh signifikan negatif sedangkan pemeriksaan pajak dan penagihan pajak berpengaruh signifikan positif. Untuk peneliti yang ingin mengambil tema yang sama dengan penelitian ini dapat mengembangkan dengan penambahan variabel bebas dan tahun penelitian yang lebih panjang sehingga didapat hasil yang lebih mencerminkan kondisi sebenarnya.

\section{Pendahuluan}

Pajak merupakan sumber utama penerimaan negara, berdasarkan UndangUndang Anggaran Pendapatan Belanja Negara (APBN) setiap tahunnya lebih dari 70\% (tujuh puluh persen) pendapatan Negara dalam postur APBN (Anggaran Pendapatan dan Belanja Negara) bersumber dari penerimaan pajak. Peningkatan anggaran dalam APBN secara langsung berdampak pada target penerimaan pajak yang meningkat setiap tahunnya. Banyaknya target pembangunan yang dilakukan dalam kurun waktu 3 (tiga) tahun terakhir mengakibatkan jumlah dana yang dibutuhkan oleh pemerintah dalam belanja modal dan belanja barang mengalami kenaikan yang signifikan. Ditambah lagi pengeluaran dari pos-pos lain dalam APBN yang memang harus mengalami kenaikan dalam upaya meningkatkan kesejahteraan rakyat Indonesia, menjaga kedaulatan negara sampai kepada pemenuhan kewajiban pemerintah guna menjaga posisi kemampuan Indonesia dalam pemeliharaan hutang serta kepercayaan investasi atas kesehatan iklim usaha dan ekonomi di Indonesia. Pengeluaranpengeluaran tersebut mulai dari anggaran pendidikan, anggaran kesehatan, anggaran pertahanan dan keamanan, pembayaran hutang dan pembayaran bunga yang jatuh tempo.
Secara garis besar pajak di Indonesia terdiri dari Pajak Pertambahan Nilai (PPN) dan Pajak Penjualan Barang Mewah (PPnBM), Pajak Penghasilan (PPh), Pajak Bumi dan Bangunan (PBB), Bea Materai (BM) dan beberapa pajak daerah. Postur penerimaan APBN dari sektor pajak terdiri dari Pajak Pertambahan Nilai (PPN) dan Pajak Penjualan Barang Mewah (PPnBM), Pajak Penghasilan (PPh), Pajak Bumi dan Bangunan (PBB) Pertambangan dan Perkebunan dan Bea Materai (BM). Dan tidak termasuk penerimaan pajak daerah dan sebagian Pajak Bumi dan Bangunan (PBB) sektor perkotaan dan pedesaan. Dimana penerimaan pajak dari sektor pajak dalam APBN disebut juga dengan nama pajak pusat. Dari jenis-jenis pajak pusat tersebut, Pajak Penghasilan memiliki peranan dan kontribusi terbesar dalam penerimaan negara dari sektor pajak. Hal ini cukup beralasan karena Pajak Penghasilan memiliki objek pengenaan yang paling luas dibandingkan dengan jenis pajak yang lain. Berdasarkan Pasal 4 ayat (1) Undang-undang Nomor 36 Tahun 2008 tentang Pajak Penghasilan, disebutkan bahwa objek pajak penghasilan adalah setiap tambahan kemampuan ekonomis yang diterima atau diperoleh oleh wajib pajak, baik yang berasal dari Indonesia maupun dari luar Indonesia, yang dapat dipakai untuk konsumsi atau untuk menambah kekayaan wajib pajak. Konsep pemajakan seperti ini dikenal dengan nama 
World Wide Income. Selain karena objek pemajakan yang luas, faktor yang menjadikan pajak penghasilan sebagai jenis pajak pemberi kontribusi terbesar dalam penerimaan negara dari sektor pajak adalah karena subjek pajak yang dimiliki. Dimana subjek pajak penghasilan terdiri dari setiap orang pribadi, warisan yang belum terbagi sebagai satu kesatuan menggantikan yang berhak, badan dan bentuk usaha tetap (BUT). Dengan melihat luas dan besarnya objek dan subjek pajak, seharusnya Pajak Penghasilan Badan menjadi kontribusi penerimaan terbesar untuk jenis pajak pada Pajak Penghasilan. Dengan pengelolaan yang baik, maka realisasi penerimaan pajak dari jenis Pajak Penghasilan Badan dapat ditingkatkan setiap tahunnya. Dengan menjalankan tiga pilar sistem perpajakan (kebijakan pajak, hukum pajak dan administrasi perpajakan) dengan sebaikbaiknya ditengah semakin dinamis dan kompleksnya setiap transaksi dan derivatifnya pada dunia usaha saat ini baik secara domestik maupun lintas negara (cross border).

Sosialisasi merupakan media yang digunakan pemerintah dalam penyampaian kebijakannya, sesuai dengan konsep sosialisasi itu sendiri yang dikemukakan oleh Harton dan Hunt (1987) yang menyatakan bahwa sosialisasi adalah proses dimana seorang menghayati (internalize) norma-norma kelompok dimana ia hidup sehingga timbulah diri yang unik. Melalui proses inilah, norma dan keterampilan diajarkan kepada individu agar dapat hidup secara normal dalam masyarakatnya.

Adapun kegiatan pengawasan tersebut dimandatkan kepada petugas yang disebut dengan Account Reprsentative dimana tugas dan fungsinya tertuang dalam Keputusan Menteri Keuangan Nomor 98 Tahun 2006 tentang Tugas dan Fungsi Account Representative.

Selanjutnya pemeriksaan untuk pengujiannya (Pasal 1 angka 25 Undang Undang Nomor 28 Tahun 2007). Dalam pengujian tesebut akan menimbulkan hasil berupa ketetapan pajak yang menyatakan bahwa wajib pajak telah melakukan dengan benar seluruh kewajiban perpajakannya (ditandai dengan ketetapan pajak Nihil), memiliki kelebihan pembayaran pajak dalam rangka pemenuhan kewajiban perpajakannya (ditandai dengan ketetapan pajak Lebih Bayar) atau memiliki kekurangan pembayaran pajak dalam pemenuhan kewajiban perpajakannya (ditandai dengan ketetapan pajak Kurang Bayar).

Atas kondisi terakhir diatas, terdapat rangkaian kegiatan lainnya yang akan dilakukan untuk menagih kekurangan pembayaran pajak tersebut (utang pajak) yang disebut dengan penagihan pajak. Di dalam penagihan pajak ini terdapat berbagai macam kegiatan dari mulai penerbitan surat teguran kepada wajib pajak atas utang pajaknya sampai dengan penyanderaan, pencegahan dan pelelangan aset yang disita (Pasal 1 angka 9 Undang - Undang tetapi disisi lain juga mengedepankan asas toleransi berupa mengakomodasi niat baik wajib pajak yang ingin membayar utang pajaknya tetapi tidak sanggup jika dilakukan sekaligus dengan cara mengangsur utang pajak tersebut. Rangkaian kegiatan penagihan pajak ini juga diharapkan sebagai shock therapy kepada wajib pajak sehingga sesegera mungkin patuh untuk berniat membayar atas utang pajak yang timbul.

Beberapa penelitian tentang kegiatan sosialisasi berpengaruh terhadap kepatuhan wajib pajak diantaranya yang dilakukan oleh Wardani,dkk (2018) dan Boediono, dkk (2018) menyatakan bahwa sosialiasi perpajakan berpengaruh positif terhadap kepatuhan wajib pajak. Sedangkan penelitian atas kepatuhan terhadap penerimaan pajak yang dilakukan oleh Rahman (2017) menyatakan bahwa berpengaruh terhadap penerimaan.

Berdasarkan penelitian Rachmawati, dkk (2014) pengawasan berpengaruh positif dan signifikan tetapi hasil penelitian yang berbeda yang dilakukan oleh Aswari dan Dudi (2015) pengawasan tidak berpengaruh terhadap tingkat kepatuhan pajak pengahasilan badan.Penelitian yang dilakukan Mandagi, dkk (2014) menyatakan bahwa pemeriksaan pajak berpengaruh terhadap kepatuhan wajib pajak senada dengan Wahda, dkk (2018). Pada penelitian yang dilakukan oleh Rosyidi (2014) penagihan berpengaruh signifikan terhadap kepatuhan wajib pajak.

Dan pada penelitian Yeni (2013), Darmayani dan Eva (2017) Wulandari (2015), Simamora dan Suryaman (2015) kepatuhan wajib pajak berpengaruh positif dan signifikan terhadap penerimaan pajak. 
Berdasarkan uraian diatas, peneliti bermaksud mengujibagaimana pengaruh sosialisasi kebijakan pajak, pengawasan, pemeriksaan dan penagihan pajak terhadap penerimaan pajak penghasilan badan dengan kepatuhan wajib pajak sebagai variabel perantara.

\section{Telaah Teori dan Pengembangan Hipotesis}

Teori Welfare State adalah Teori yang menegaskan bahwa Negara yang pemerintahannya menjamin terselenggaranya kesejahteraan rakyat. Prinsip dasar teori Walfare State, yakni bahwa negara/pemerintah bertanggung jawab penuh untuk menyediakan semua kebutuhan rakyatnya dan tidak dapat dilimpahkan kepada siapapun (Abercrombie, 2000). Hal tersebut dituangkan didalam batang tubuh Undang-Undang Dasar 1945 dimana negara menjamin setiap hak bagi seluruh rakyat Indonesia yaitu kebebasan berkumpul dan mengeluarkan pendapat, keamanan dan ketertiban, kehidupan yang layak, mendapatkan pekerjaan sampai dengan memelihara fakir miskin dan anak terlantar. Dalam mewujudkan kesejahteraan bagi rakyatnya. Negara membutuhkan sumber pendapatan. Pendapatan tersebut dituangkan dalam batang tubuh Undang-Undang Dasar 1945 pasal 23A disebutkan bahwa Pajak Dan Pungutan Lain Yang Bersifat Memaksa Untuk Keperluan Negara Diatur Dengan Undang-Undang. Direktorat Jenderal Pajak merupakan lembaga negara yang diamanahkan mengumpulkan penerimaan negara dalam bentuk pajak dengan merumuskan dan melaksanakan kebijakan dan standardisasi teknis di bidang perpajakan serta administrasi perpajakan. Atas tugas dan fungsi tersebut dalam mengumpulkan penerimaan negara. Direktorat Jenderal Pajak dalam hal ini diwakili oleh Kantor Wilayah DJP Jakarta Timur melaksanakan sosialisasi kebijakan pajak, pengawasan wajib pajak, pemeriksaan pajak dan penagihan pajak untuk mencapai target penerimaan pajak yang telah ditetapkan dan meningkatkan kepatuhan wajib pajak atas kewajiban perpajakannya. Dimana salah satu penerimaan pajak tersebut adalah penerimaan Pajak Penghasilan (PPh) Badan.

\subsection{Sosialisasi kebijakan pajak dan penerimaan pajak}

Sosialisasi kebijakan pajak merupakan rangkaian upaya yang dilakukan untuk dapat memberikan pengetahuan dan pemahaman kepada wajib pajak atas peraturan perpajakan yang terus menerus berubah secara dinamis mengikuti perkembangan transaksi ekonomi yang ada pada suatu Negara.

Wardani, dkk (2018) menyatakan sosialisasi tentang pajak, diharapkan dapat membuat wajib pajak mengetahui, memahami, dan menyadari pentingnya pajak bagi pembangunan. Dengan demikian, wajib pajak merespon diadakannya sosialisasi perpajakan yang diberikan. Kehadiran wajib pajak dalam mengikuti sosialisasi perpajakan, menyebabkan wajib pajak mengetahui, memahami, dan menyadari pentingnya pajak bagi pembangunan, sehingga wajib pajak lebih patuh dalam melaksanakan kewajiban perpajakan. Hal ini menyebabkan sosialisasi perpajakan berpengaruh terhadap kepatuhan wajib pajak.

Berdasarkan uraian tersebut, maka hipotesis yang dapat dirumuskan adalah :

H1a : Sosialisasi kebijakan pajak berpengaruh terhadap kepatuhan wajib pajak

$\mathrm{H} 1 \mathrm{~b}$ : Sosialisasi kebijakan pajak berpengaruh terhadap penerimaan pajak melalui kepatuhan wajib pajak

\subsection{Pengawasan wajib pajak dan Penerimaan pajak}

Pengawasan wajib pajak merupakah upaya yang dilakukan oleh Direktorat Jenderal Pajak dalam upaya menghimpun penerimaan negara. Pengawasan yang melekat kepada setiap wajib pajak atas transaksi ekonominya. Diharapkan dapat memberikan peringatan dini kepada wajib pajak atas pentingnya melakukan pemenuhan kewajiban perpajakan sesuai dengan ketentuan perundang-undangan yang berlaku.

Dalam penelitian Widomoko dan Nofriyanti (2018) menyatakan pengawasan yang dilaksanakan oleh Account Representative sudah cukup baik dari sisi lingkungan kepatuhan bahwa telah ditaatinya peraturan, telah menerapkan nilai integritas yang tinggi, etika dan sikap yang cukup baik. Kondisi seperti ini memperlihatkan bahwa semakin tinggi tingkat pengawasan yang dilaksanakan 
oleh Account Representative maka akan semakin tinggi pula kepatuhan wajib pajaknya.

Berdasarkan uraian tersebut, maka hipotesis yang dapat dirumuskan adalah:

H2a : Pengawasan wajib pajak berpengaruh terhadap kepatuhan wajib pajak

$\mathrm{H} 2 \mathrm{~b}$ : Pengawasan wajib pajak berpengaruh terhadap penerimaan pajak melalui kepatuhan wajib pajak

\subsection{Pemeriksaan Pajak dan Penerimaan Pajak}

Pemeriksaan pajak merupakan kunci dari sistem penilaian diri (self assement system) dimana menurut Undang-Undang No.28 Tahun 2007 pemeriksaan pajak adalah serangkaian kegiatan untuk mencari, mengumpulkan, mengelola data dan atau keterangan lainnya untuk menguji kepatuhan pemenuhan kewajiban perpajakan dan untuk tujuan laian dalam rangka melaksanakan ketentuan peraturan perundang-undangan perpajakan.

Teori yang menghubungkan antara Pengaruh Pemeriksaan Pajak terhadapKepatuhan Wajib Pajak disebutkan oleh Sumarsan (2017), bahwa pemeriksaan pajak adalah serangkaian kegiatan menghimpun dan mengolah data, keterangan dan/atau bukti yang dilaksanakan secara objektif dan professional berdasarkan suatu standar pemeriksaan untuk menguji kepatuhan pemenuhan kewajiban perpajakan dan/atau untuk tujuan lain dalam rangka melaksanakan ketentuan peraturan perundang undangan perpajakan. Sedangkan Rahayu (2010) menyatakan bahwa kepatuhan Wajib Pajak dipengaruhi oleh beberapa faktor yaitu kondisi sistem administrasi perpajakan suatu Negara, pelayanan pada Wajib Pajak, penegakan hukum perpajakan, pemeriksaan pajak, dan tarif pajak.

Teori diatas diperkuat dengan penelitian Mandagi, dkk (2014) bahwa koefisien determinasi menunjukkan tingkat kepatuhan wajib Pajak badan dipengaruhi pelaksanaan pemeriksaan pajak sebesar $64,7 \%$.Berdasarkan uraian teori beserta penelitian terdahulu diatas, maka dapat diambil kesimpulan sementara bahwa Pemeriksaan Pajak memiliki pengaruh terhadap Kepatuhan Wajib Pajak, yang artinya apabila Pemeriksaan Pajak dilakukan dengan baik maka akan meningkatkan kepatuhan Wajib Pajak.

Berdasarkan uraian tersebut, maka hipotesis yang dapat dirumuskan adalah:

H3a : Pemeriksaan pajak berpengaruh terhadap kepatuhan wajib pajak

$\mathrm{H} 3 \mathrm{~b}$ : Pemeriksaan pajak berpengaruh terhadap penerimaan pajak melalui kepatuhan wajib pajak

\subsection{Penagihan Pajak dan Penerimaan Pajak}

Berdasarkan Pasal 1 angka 9 UndangUndang Nomor 19 Tahun 2000 tentang Penagihan Pajak dengan Surat Paksa disebutkan bahwa penagihan pajak adalah serangkaian tindakan agar Penanggung Pajak melunasi utang pajak dan biaya penagihan pajak dengan menegur atau memperingatkan, melaksanakan penagihan seketika dan sekaligus, memberitahukan Surat Paksa, mengusulkan pencegahan, melaksanakan penyitaan, melaksanakan penyanderaan, menjual barang yang telah disita. Sehubungan dengan kegiatan penagihan tersebut, penagihan pajak memiliki pengaruh yang signifikan terhadap kepatuhan wajib pajak sesuai dengan penelitian Rosyidi (2014).

Berdasarkan uraian tersebut, maka hipotesis yang dapat dirumuskan adalah:

H4a : Penagihan pajak berpengaruh terhadap kepatuhan wajib pajak

H4b: Penagihan pajak berpengaruh signifikan terhadap penerimaan pajak melalui kepatuhan wajib pajak

\subsection{Kepatuhan Wajib Pajak dan Penerimaan Pajak}

Nurmanto dalam Rahayu (2010) mengatakan bahwa kepatuhan perpajakan dapat didefinisikan sebagai suatu keadaan di mana Wajib Pajak memenuhi semua kewajiban perpajakan dan melaksanakanhak perpajakannya. Sedangkan Priantara (2002) menyatakan bahwa peran serta Wajib Pajak dalam memenuhi kewajiban pembayaran pajak berdasarkan ketentuan perpajakan sangat diharapkan, kepatuhan Wajib Pajak dalam membayar pajak merupakan posisi strategis dalam peningkatan penerimaan pajak. 
Pernyataan diatas diperkuat dengan penelitian yang dilakukan oleh Darmayani dan Eva (2017) yang menyatakan bahwa Kepatuhan wajib pajak berpengaruh positif dan signifikan terhadap penerimaan pajak. Berdasarkan hal tersebut diatas, maka dapat diambil kesimpulan semakin tinggi tingkat Kepatuhan Wajib Pajak maka semakin besar penerimaan pajak.

Berdasarkan uraian tersebut, maka hipotesis yang dapat dirumuskan adalah:

H5 : Kepatuhan wajib pajak berpengaruh terhadap penerimaan pajak

\section{Metode Penelitian}

Objek penelitian ini adalah seluruh KPP di Kanwil DJP Jakarta Timurdengan rentang waktu penelitian selama 5 (lima) tahun dari tahun 2014-2018. Penelitian fokus pada hasil kerja setiap kegiatan yang merupakan variable independen dengan membandingkan antara target dan realisasi pekerjaan. Skala pengukuran yang digunakan adalah skala rasio.

Teknik analisis data yang digunakan adalah analisis jalur (path analysis) dengan program SPSS. Analisis jalur merupakan perluasan dari analisis linear berganda, atau analisis jalur adalah penggunaan analisis regresi untuk menaksir hubungan kausalitas antar variabel (model kausal) yang telah ditetapkan sebelumnya berdasarkan teori (Ghozali, 2013). Analisis jalur sendiri tidak menentukan hubungan sebab-akibat dan juga tidak dapat digunakan sebagai subtitusi bagi peneliti untukmelihat hubungan kausalitas antar variabel. Hubungan kausalitas antar variabel telah dibentuk dengan model berdasarkan landasan teoritis. Apa yang dilakukan oleh analisis jalur adalah menentukan pola hubungan antara tiga atau lebih variabel dan tidak dapat digunakan untuk mengkonfirmasi atau menolak hipotesis kausalitas imajiner.Juliansyah Noor (2014) menyatakan bahwa Diagram jalur dapat digunakan untuk menghitung pengaruh langsung dan tidak langsung dari variabel Independen terhadap suatu variabel dependen. Pengaruh-pengaruh itu tercermin dalam apa yang disebut dengan koefisien jalur, dimana secara matematik analisis jalur mengikuti model struktural.

\section{Hasil Penelitian dan Pembahasan}

Data kinerja sosialisasi kebijakan pajak untuk 9 KPP yang berada di Kantor Wilayah DJP Jakarta Timur memiliki nilai minimum sebesar 57,15\% dan nilai maksimum 153,3\%. Dengan nilai rata-rata/mean sebesar $99,5 \%$ yang berarti bahwa kinerja fungsi sosialisasi kebijakan pajak cendrung tercapai secara keseluruhan.Untuk data kinerja pengawasan wajib pajak untuk 9 KPP yang berada di Kantor Wilayah DJP Jakarta Timur memiliki nilai minimum sebesar $44,7 \%$ dan nilai maksimum $155,8 \%$. Dengan nilai rata-rata/mean sebesar $89,5 \%$ yang berarti bahwa kinerja fungsi pengawasan wajib pajak masih belum maksimal. Sedangkan data kinerja pengawasan wajib pajak untuk 9 KPP yang berada di Kantor Wilayah DJP Jakarta Timurmemiliki nilai minimum sebesar $35,7 \%$ dan nilai maksimum $157,9 \%$. Dengan nilai rata-rata/mean sebesar 93,4\% yang berarti bahwa kinerja fungsi pemeriksaan pajak masih belum maksimal. Selanjutnya data kinerja pengawasan wajib pajak untuk 9 KPP yang berada di Kantor Wilayah DJP Jakarta Timur memiliki nilai minimum sebesar $60,0 \%$ dan nilai maksimum $155,2 \%$. Dengan nilai rata-rata/mean sebesar $95,4 \%$ yang berarti bahwa kinerja fungsi penagihan pajak mendekati maksimal. Data kepatuhan wajib pajak untuk 9 KPP yang berada di Kantor Wilayah DJP Jakarta Timur memiliki nilai minimum sebesar $64,9 \%$ dan nilai maksimum $128,3 \%$. Dengan nilai ratarata/mean sebesar $91,7 \%$ yang berarti bahwa secara keseluruhan kepatuhan wajib pajak sudah cukup baik. Data penerimaan PPh Badan memiliki nilai minimum sebesar $65,4 \%$ dan nilai maksimum $123,6 \%$. Dengan nilai ratarata/mean sebesar $86,8 \%$ yang berarti bahwa penerimaan PPh Badan belum cukup maksimal. 平

\begin{tabular}{|l|l|l|}
\hline & Model 1(Kepatuhan) & Model 2(Penerimaan) \\
\hline R-square & 0.353 & 0.441 \\
\hline Adjusted R-square & 0.288 & 0.370 \\
\hline
\end{tabular}

Nilai Adjusted $R$ square pada model 1 dalam penelitian ini adalah sebesar 0,288 memiliki arti bahwa 4 variabel independen berpengaruh pada kepatuhan wajib pajak sebagai variable dependen atau kemampuan variabel independen untuk menjelaskan besarnya variasi dalam variabel dependen adalah sebesar $28,8 \%$, sedangkan sisanya 
sebesar $71,2 \%$ dijelaskan variable lain yang tidakmasuk dalam persamaan, yang mempengaruhi tingkat kepatuhan wajib pajak.

Adjusted $R$ square pada model 2 dalam penelitian adalah sebesar 0,370 memiliki arti bahwa sosialisasi kebijakan pajak, pengawasan wajib pajak, pemeriksaan pajak dan penagihan pajak berpengaruh pada penerimaan PPh Badan sebesar $37,0 \%$ dimana kepatuhan wajib pajak sebagai variable perantara, sedangkan sisanya sebesar $63,0 \%$ dijelaskan variable lain yang tidak masuk dalam persamaan, yang mempengaruhi penerimaan PPh Badan.

\section{Rangkuman Hasil Pegujian}

\begin{tabular}{|c|c|c|c|c|c|c|}
\hline \multirow[b]{2}{*}{ Variabel } & \multicolumn{3}{|c|}{$\begin{array}{c}\text { Model } 1 \\
\text { (Kepatuhan) }\end{array}$} & \multicolumn{3}{|c|}{$\begin{array}{c}\text { Model } 2 \\
\text { (Penerimaan) }\end{array}$} \\
\hline & Coeff & $\begin{array}{c}\text { t- } \\
\text { hitung }\end{array}$ & sig & coeff & t-hitung & sig \\
\hline $\begin{array}{l}\text { Sosialisasi } \\
\text { Kebijakan } \\
\text { Pajak }\end{array}$ & .184 & 3.632 & .001 & -.184 & -2.433 & .020 \\
\hline $\begin{array}{l}\text { Pengawasan } \\
\text { Wajib Pajak }\end{array}$ & .219 & 2.683 & .011 & -.223 & -2.702 & .010 \\
\hline $\begin{array}{l}\text { Pemeriksaan } \\
\text { Pajak }\end{array}$ & .042 & 2.966 & .005 & .112 & 2.082 & .044 \\
\hline $\begin{array}{l}\text { Penagihan } \\
\text { Pajak }\end{array}$ & .093 & .789 & .435 & .180 & 2.153 & .038 \\
\hline $\begin{array}{l}\text { Kepatuhan } \\
\text { Wajib Pajak }\end{array}$ & & & & .612 & 3.830 & .000 \\
\hline F-hitung & & & 5.453 & & & 6.164 \\
\hline Sig-F & & & 0,001 & & & 0.000 \\
\hline
\end{tabular}

Berdasarkan model 1 tabel $d$ atas didapatkan persamaan regresi sebagai berikut:

$\mathrm{KWP}=41,028+0,184 \mathrm{SK}+0,219 \mathrm{PWP}+$ 0,042 PP + 0,093 PnP+11,295+e.

Nilai t hitung untuk variabel sosialisasi kebijakan diperoleh sebesar 3,632 lebih besar dari t tabel yaitu 1,679 dan memiliki nilai signifikansi di bawah 5\% yaitu sebesar 0,001 yang dapat diartikan bahwa sosialisasi berpengaruh signifikan terhadap kepatuhan wajib pajak. Untuk variabel Pengawasan Wajib Pajak diperoleh sebesar 2,966 dengan nilai signifkansi 0,011. Sehingga dapat simpulkan bahwa pengawasan wajib pajak berpengaruh signifikan terhadap kepatuhan wajib pajak. Pada variabel pemeriksaan pajak diperoleh nilai t hitung sebesar 0,789 dimana nilai tersebut lebih kecil dari nilai t tabel dan nilai signifkansi yang di peroleh lebih besar dari tingkat signifkansi yaitu sebesar 0,435 sehingga dapat diartikan bahwa pemeriksaan pajak tidak berpengaruh signifikan terhadap kepatuhan wajib pajak. Sedangkan penagihan pajak memiliki t hitung sebesar 1,141 dengan nilai signifikansi sebesar 0,261 sehingga diartikan bahwa penagihan tidak berpengaruh signifikan terhadap kepatuhan wajib pajak. Dari tabel diatas diketahui nilai $\mathrm{F}$ hitung sebesar 5,453 lebih besar dibandingkan dengan $\mathrm{F}$ tabel pada signifikan $5 \%$ yaitu 2,46 dengan nilai signifikansi sebesar 0,001 . Sehingga dapat diartikan bahwa sosialisasi kebijakan, pengawasan wajib pajak, pemeriksaan pajak dan penagihan pajak secara bersama-sama berpengaruh signifikan terhadap kepatuhan wajib pajak. 
Berdasarkan model 2 tabel diatas didapatkan persamaan regresi sebagai berikut:

$$
\mathrm{PnPB}=39,231-0,184 \mathrm{SK}-0,223 \mathrm{PWP}+
$$
$0,112 \mathrm{PP}+0,180 \mathrm{PnP}+0,612 \mathrm{KWP}+13.173$ $+\mathrm{e}$.

Nilai t hitung untuk variabel sosialisasi kebijakan diperoleh sebesar 2,433 lebih besar dari $\mathrm{t}$ tabel yaitu 1,679 dan memiliki nilai signifikansi di bawah 5\% yaitu sebesar 0,005 yang dapat diartikan bahwa sosialisasi berpengaruh signifikan terhadap penerimaan pajak melalui kepatuhan wajib pajak. Untuk variabel Pengawasan Wajib Pajak diperoleh sebesar 2,702 dengan nilai signifkansi 0,010. Sehingga dapat simpulkan bahwa pengawasan wajib pajak berpengaruh signifikan terhadap penerimaan pajak melalui kepatuhan wajib pajak. Pada variabel pemeriksaan pajak diperoleh nilai $t$ hitung sebesar 2,082 dimana nilai tersebut lebih besar dari nilai t tabel dan nilai signifkansi yang di peroleh sebesar 0,044 sehingga dapat diartikan bahwa pemeriksaan pajak berpengaruh signifikan terhadap penerimaan pajak melalui kepatuhan wajib pajak. Sedangkan penagihan pajak memiliki t hitung sebesar 2,138 dengan nilai signifikansi sebesar 0,038 sehingga diartikan bahwa penagihan pajak berpengaruh signifikan terhadap penerimaan pajak melalui kepatuhan wajib pajak. Untuk variabel kepatuhan wajib pajak memiliki nilai t hitung sebesar 3,830 dengan nilai signifikasi sebesar 0,000 maka dapat diartikan bahwa kepatuhan wajib pajak berpengaruh signifikan terhadap penerimaan pajak. Dari tabel diatas diketahui nilai F hitung sebesar 6,164 lebih besar dibandingkan dengan $\mathrm{F}$ tabel pada signifikan 5\% yaitu 2,46 dengan nilai signifikansi sebesar 0,000 . Sehingga dapat diartikan bahwa sosialisasi kebijakan, pengawasan wajib pajak, pemeriksaan pajak dan penagihan pajak secara bersama-sama berpengaruh signifikan terhadap penerimaan pajak melalui kepatuhan wajib pajak.

\subsection{Pengaruh Sosialisasi Kebijakan Terhadap Kepatuhan Wajib Pajak dan Penerimaan Pajak dengan Kepatuhan sebagai Perantara}

Sosialisasi merupakan media yang digunakan dalam menyampaikan kebijakan pajak yang dituangkan dalam peraturan perpajakan. Penyampaian informasi tersebut diharapkan menambah pengetahuan yang dimiliki oleh wajib pajak atas kewajibannya dan memahami dengan baik sehingga dapat menyampaikan dengan benar sesuai ketentuan yang berlaku baik secara formal dan material. Dimana pemenuhan kewajiban perpajakan secara formal dan material sesuai ketentuan yang berlaku merupakan bentuk kepatuhan wajib pajak. Dalam penelitian diperoleh bahwa sosialisasi berpengaruh signifikan terhadap kepauhan wajib pajak, hal ini sesuai dengan hasil penelitian Wardani, dkk (2018) yang menyimpulkan bahwa terdapat pengaruh yang signifikan antara sosialisasi kebijakan terhadap kepatuhan wajib pajak. Wulandari (2015) menyatakan bahwa apabila terjadi peningkatan sosialisasi yang dilakukan kantor pelayanan pajak maka akan meningkatkan kepatuhan wajib pajak. Semakin sering kegiatan sosialisasi kebijakan pajak dilakukan, semakin banyak wajib pajak yang melakukan kewajiban perpajakannya.

Semakin tinggi tingkat pemahaman wajib pajak atas kebijakan yang terutang dalam peraturan perpajakan maka akan memberikan cara untuk dapat melakukan penghindaran pajak. Disamping itu kebijakan pemerintah terkait investasi menghadirkan adanya insentif kebijakan pajak yang memberikan wajib pajak lebih banyak ruang penghematan pajak yang harus dibayarkan untuk nantinya bisa direinvestasikan lagi dalam pengembangan usaha dan meningkatkan daya saing di pasar domestik dan internasional. Hal-hal tersebut merupakan dugaan peneliti atas hasil penelitian bahwa sosialiasi kegiatan pajak berpengaruh signifikan negatif terhadap penerimaan $\mathrm{PPh}$ Badan melalui kepatuhan .

Penelitian Rahman (2017) menyatakan bahwa Kegiatan sosialisasi bagi calon Wajib Pajak bertujuan untuk membangun awareness tentang pentingnya pajak serta menjaring Wajib Pajak baru. Kegiatan sosialisasi bagi Wajib Pajak baru bertujuan untuk meningkatkan pemahaman dan kepatuhan untuk memenuhi kewajiban perpajakannya, khususnya bagi mereka yang belum menyampaikan SPT dan belum melakukan penyetoran pajak untuk yang pertama kali.

Sedangkan kegiatan sosialisasi bagi Wajib Pajak terdaftar bertujuan untuk menjaga komitmen Wajib Pajak untuk terus patuh. Oleh karena itu dengan diadakannya kegiatan 
sosialisasi ini diharapkan akan terciptanya partisipasi yang efektif dari masyarakat dalam memenuhi hak dan kewajiban sebagai wajib pajak sehingga adanya kesadaran dari wajib pajak untuk menyampaikan pajaknya dan hal tersebut akan membuat penerimaan pajak penghasilan badan pun akan lebih meningkat.Hasil penelitian ini tidak sejalan dengan penelitian yang dilakukan oleh Herryanto dan Toly (2013) yang menyatakan tidak berpengaruhnya sosialisasi signifikan disebabkan karena sebagian besar Wajib Pajak mengikuti kegiatan sosialisasi perpajakan hanya sebagai suatu keharusan karena bersifat memaksa, akan tetapi tetap saja tidak menjalankan kewajibannya dengan patuh.

\subsection{Pengaruh Pengawasan Pengawasan Wajib Pajak Terhadap Kepatuhan Wajib Pajak dan Penerimaan PPh Badan dengan Kepatuhan sebagai Perantara}

Pengawasan wajib pajak merupakan kegiatan dalam rangka memastikan bahwa pajak yang dilaporkan dan disetorkan oleh wajib pajak sesuai dengan ketentuan yang berlaku. Hasil penelitian menunjukkan bahwa pengawasan wajib pajak berpengaruh signifikan terhadap kepatuhan wajib pajak. Hal ini sesuai dengan hasil penelitian Widomoko dan Nofriyanti (2018) yang menyimpulkan bahwa terdapat pengaruh yang signifikan antara pengawasan wajib pajak terhadap kepatuhan wajib pajak. Pengawasan yang diberikan dapat mengawasi dan mengingatkan wajib pajak tentang kewajiban wajib pajak, memahami proses bisnis wajib pajak menyebabkan kondisi wajib pajak menjalankan setiap aktivitas ekonomi sesuai dengan aturan yang berlaku atau dengan kata lain wajib pajak menjalankan kewajiban perpajakannya sesuai ketentuan yang berakibat peningkatan kepatuhan wajib pajak. Hasil penelitian ini juga konsisten dengan penelitian yang dilakukan oleh Nofri, Sukmawati dan Ramadhan dalam Widomoko dan Nofriyanti (2018).

Hasil penelitian pengawasan wajib pajak terhadap penerimaan $\mathrm{PPh}$ Badan dengan kepatuhan sebagai perantara berpengaruh signifikan negatif. Peneliti menduga disebabkan beberapa hal diantaranya lambatnya pemerataan kemampuan petugas pajak yang bertugas melakukan pengawasan (Account Representative) dalam hal analisa laporan keuangan yang menjadi dasar perhitungan PPh Badan. Dimana pengawasan yang dilakukan kepada wajib pajak cenderung terkonsentrasi hanya terhadap timeline pembayaran dan pelaporan melewati waktu yang ditentukan. Kemudian pengawasan atas bukti-bukti kongkrit seperti faktur pajak. Selanjutnya keterbatasan akses yang dapat dilakukan oleh petugas tersebut terhadap datadata yang dibutuhkan untuk melakukan penghitungan jumlah pajak PPh Badan yang seharusnya dibayar oleh wajib pajak. Dan keterbatasan jumlah pegawai yang melakukan pengawasan integritas pegawai yang berjumlah 42.000 lebih yang tersebar di seluruh Indonesia memberikan ruang kepada oknum melakukan tindakan-tindakan pelanggaran. Penelitian yang dilakukan Rizkilina dan Pratomo (2015) yang menyimpulkan bahwa pengawasan tidak berpengaruh signifikan terhadap penerimaan pajak. Hal ini disebabkan oleh wajib pajak yang kurang memahami objek-objek pajak serta tidak tepat dalam penerapan tarif pajak. Sehingga sudah dilakukan penyuluhan secara rutin belum menjamin wajib pajak dalam pemahaman objek pajak dan ketepatan penerapan tarif pajak yang menjadi indikator untuk mengukur Tingkat Kepatuhan Pajak Penghasilan Badan.

\subsection{Pengaruh Pemeriksaan Pajak Terhadap Kepatuhan Wajib Pajak dan Penerimaan PPh Badan dengan Kepatuhan sebagai Perantara}

Hasil penelitian pengaruh pemeriksaan pajak terhadap kepatuhan tidak signifikan diduga disebabkan oleh pemeriksaan yang dilakukan dengan cara sampling bukan populasi dan tidak setiap tahun atas seluruh wajib pajak yang terdaftar di Kantor Pelayanan Pajak memberikan sebuah ruang bahwa pemeriksaan bukan menjadi sesuatu hal yang menjadi perhatian wajib pajak sehingga tidak memiliki dampak terhadap kepatuhan wajib pajak. Hal ini dapat dilihat dari penelitian Rizkilina dan Pratomo (2015) yang menyimpulkan bahwa tidak terdapat pengaruh yang signifikan antara pemeriksaan pajak terhadap kepatuhan wajib pajak. Dalam Rizkilina dan Pratomo (2015) penelitian ini 
sejalan dengan hasil penelitian Aulia dan Pamungkas yang menyatakan bahwa pemeriksaan pajak tidak berpengaruh terhadap kepatuhan pajak.

Hasil dari kegiatan pemeriksaan pajak adalah ketetapan pajak baik berupa Surat Ketetapan Pajak maupun Surat Tagihan Pajak dimana dua ketetapan tersebut menimbulkan hutang pajak yang harus dibayarkan oleh wajib pajak. Sehingga atas pemeriksaan tersebut menghasilkan penerimaan negara. Penelitian Febriyanti (2013), Mandagi, dkk (2014), Mohammad, dkk (2017) dan Rahman (2017) tentang pemeriksaan pajak berpengaruh positif dan signifikan terhadap penerimaan pajak sejalan dengan hasil penelitian yang dilakukan oleh peneliti bahwa pemeriksaan pajak memiliki pengaruh signifikan terhadap penerimaan pajak dengan kepatuhan sebagai perantara.

Pemeriksaan pajak yang dilakukan melibatkan pegawai pajak dengan fungsi pengawasan dalam rangka mencari bukti awal dalam penyusunan audit plan dan audit program dalam rangka pemeriksaan. Temuan pemeriksaan dapat berupa beda waktu atau beda tetap dari penghitungan yang dilakukan oleh wajib pajak disisi yang lain Tax Planning yang dilakukan oleh wajib pajak juga mendorong terjadinya kekurangan pajak menurut pemeriksa pajak. Hal ini disebabkan judgement yang dilakukan tidak hanya sebatas sudah sesuai dengan aturan yang berlaku tetapi karena pajak juga menganut paham substance over form dalam menentukan sebuah transaksi terutang pajak atau tidak.

\subsection{Pengaruh Penagihan Pajak Terhadap Kepatuhan Wajib Pajak dan Penerimaan PPh Badan dengan Kepatuhan sebagai Perantara}

Penagihan pajak merupakan rangkaian kegiatan dari mulai penerbitan surat teguran, surat paksa, penyitaan aset atau pemblokiran rekening penanggung pajak, pelelangan aset sita, penyanderaan sampai dengan pencekalan ke luar negeri atas pajak yang terutang dan telah ada ketetapan hukumnya berupa Surat Ketetapan Pajak atau Surat Tagihan Pajak. Rendahnya jumlah juru sita yaitu petugas pajak yang menjalankan fungsi penagihan menjadikan wajib pajak yang memiliki hutang pajak tapi telah jatuh tempo tidak merasakan bahwa hutang pajak tersebut menjadi sebuah hal yang harus segera dilunasi karena tidak mendapatkan peringatan dari Kantor Pelayanan Pajak. Hal ini diduga merupakan penyebab hasil penelitian menunjukkan bahwa penagihan tidak memiliki pengaruh signifikan terhadap kepatuhan wajib pajak. Hal ini tidak sejalan dengan penelitian yang dilakukan oleh Rosyidi (2014) yang menyatakan bahwa penagihan berpengaruh signifikan terhadap kepatuhan wajib pajak. Hasil penelitian ini sejalan dengan penelitian Erwis (2012) dalam Rosyidi (2014) dimana disimpulkan bahwa penagihan tidak memiliki pengaruh signifikan terhadap kepatuhan wajib pajak

Penelitian Febriyanti (2013), Hudany (2015), Mohammad, dkk (2017) dan Meiliwati (2013) menyatakan bahwa penagihan pajak berpengaruh signifikan terhadap penerimaan pajak. Hal ini sejalan dengan hasil penelitian bahwa penagihan pajak berpengaruh signifikan terhadap penerimaan $\mathrm{PPh}$ Badan melalui kepatuhan wajib pajak. Peneliti berpendapat hal ini disebabkan karena kegiatan penagihan aktif yang dilakukan terhadap wajib pajak akan sangat mempengaruhi aspek psikologis yang akan dialami oleh para penanggung pajak.

Kegiatan penagihan berupa surat paksa, penyitaan aset, pemblokiran rekening, penahanan dan pencegahan keluar negeri sampai dengan pelelangan aset sita dalam rangka pelunasan hutang pajak yang nantinya tercatat sebagai bagian dari penerimaan pajak. Ditambah lagi penagihan sekaligus untuk wajib pajak yang diketahui akan melakukan pemindahan atau pengalihan asset yang dimiliki ataupun hak mendahului saat terjadi proses kepailitan di pengadilan dan penghitungan oleh kurator atas kewajiban yang harus dibayar.

Kegiatan penyitaan aset dan pemblokiran rekening tersebut tidak sebatas yang dimiliki atas nama wajib pajak badan tetapi pemblokiran rekening, penyitaan aset, penahanan, pencegahan (pencekalan) juga dilakukan terhadap para penanggung pajak yang terdiri dari direksi, komisaris, pengambil kebijakan yang tidak ada pada akta pendirian, pemegang saham sampai kepada keluarga. Halhal tersebut menjadi sesuatu yang sangat dihindari oleh wajib pajak sehingga wajib pajak akan berusahan untuk segera melakukan pembayaran pajak yang terutang agar tindakan 
penagihan hanya sampai pada kegiatan penyampaian surat paksa.

\subsection{Pengaruh Kepatuhan Wajib Pajak Terhadap Penerimaan PPh Badan}

Kepatuhan wajib pajak terdiri dari kepatuhan formal dan material. Dimana kepatuhan formal merupakan kepatuhan dalam hal pelaksanaan aturan dalam pelaporan dan pembayaran pajak atas kewajiban perpajakan dan kepatuhan material berupa kebenaran pengungkapan penghasilan, biaya dan seluruh transaksi ekonomi yang dilakukan oleh wajib pajak serta kebenaran pajak yang dibayarkan atas hal tersebut. Berdasarkan hasil penelitian pengujian hipotesis kepatuhan wajib pajak memiliki pengaruh signifikan terhadap kepatuhan wajib pajak. Hal ini sejalan dengan penelitian Darmayani dan Eva (2017), Simamora dan Suryaman (2015), Yeni (2013) tetapi tidak sejalan dengan penelitian Alfian (2013) yang menyimpulkan bahwa tidak terdapat pengaruh yang signifikan antara kepatuhan wajib pajak dengan penerimaan pajak.

\section{Kesimpulan, Keterbatasan dan Implikasi Hasil Penelitian}

Penelitian ini bertujuan untuk mengetahui pengaruh sosialisasi kebijakan, pengawasan wajib pajak, pemeriksaan pajak dan penagihan pajak terhadap kepatuhan wajib pajak dan terhadap penerimaan $\mathrm{PPh}$ Badan dengan kepatuhan wajib pajak sebagai perantara di 9 (sembilan) Kantor Pelayanan Pajak di lingkungan Kanwil DJP Jakarta Timur selama tahun 2014 sampai dengan 2018. Data diambil dengan cara populasi yang merupakan data sekunder atas kinerja dari variable di masingmasing KPP.

Dengan hasil penelitian bahwa Sosialisasi Kebijakan berpengaruh signifikan terhadap kepatuhan wajib pajak yang berarti bahwa semakin seringnya kegiatan sosialisasi maka akan meningkatkan kepatuhan wajib pajak. Dan berpengaruh signifikan negatif terhadap penerimaan PPh Badan melalui kepatuhan yang berarti Hal ini berarti pemahaman wajib pajak akan peraturan diduga memiliki kecenderungan untuk dapat memanfaatkan celah peraturan agar dapat menghemat pembayaran pajak yang seharusnya.
Pengawasan Wajib Pajak berpengaruh signifikan terhadap Kepatuhan Wajib Pajak yang berarti pengawasan oleh petugas pajak (Account Representative) terhadap kepatuhan lapor dan bayar wajib pajak memberikan dampak peningkatan kepatuhan wajib pajak dalam pemenuhan kewajibannya. Dan berpengaruh signifikan negatif terhadap penerimaan Pajak Penghasilan Badan dengan kepatuhan wajib pajak sebagai perantara dikarenakan masih kurangnya kemampuan pengawasan sehubungan dengan penerimaan PPh Badan dan banyaknya jumlah wajib pajak yang diawasi melebihi standar jumlah yang ditetapkan sehingga target penerimaan pajak yang diberikan tidak tercapai. Disisi lain kasus pelanggaran kode etik dan adanya oknum pegawai yang tidak menjaga integritas bisa menjadi celah pengawasan tidak dilakukan sebagaimana mestinya.

Hasil penelitian menunjukkan bahwa Pemeriksaan Pajak tidak berpengaruh signifikan terhadap kepatuhan wajib pajak yang berarti wajib pajak badan merasa pemeriksaan pajak bukan merupakan hal yang memberikan rasa tidak nyaman saat dilakukan pemeriksaan dan wajib pajak merasa telah melakukan pemenuhan kewajiban perpajakan dengan baik dan benar tetapi berpengaruh signifikan positif terhadap penerimaan Pajak Penghasilan Badan dengan kepatuhan wajib pajak sebagai perantara karena disebabkan hasil pemeriksaan berupa ketetapan pajak merupakan hal yang harus dipenuhi (dibayarkan) oleh wajib pajak.

Penagihan pajak tidak berpengaruh signifikan terhadap kepatuhan wajib pajak karena terjadinya ketidaksesuaian data alamat wajib pajak dengan domisili sebenarnya wajib pajak sehingga wajib pajak tidak menerima surat teguran dan surat paksa yang merupakan langkah awal penagihan aktif tetapi berpengaruh signifikan positif terhadap penerimaan Pajak Penghasilan Badan dengan kepatuhan wajib pajak sebagai perantara karena Wajib pajak berusaha melunasi hutang pajak yang dimiliki sesuai dengan peraturan yang berlaku karena penyitaan, pelelangan aset sita, pemblokiran rekening, pencekalan ke luar negeri dan penyanderaan memberikan efek jera kepada wajib pajak.

Selanjutnya hasil penelitian kepatuhan wajib pajak terhadap Pajak Penghasilan Badan diperoleh hasil bahwa kepatuhan wajib pajak 
berpengaruh signifikan terhadap penerimaan Pajak Penghasilan Badan.dan . Hal ini berarti wajib pajak melakukan pemenuhan kewajiban perpajakannya sesuai dengan peraturan perundang-undangan yang berlaku.

Implikasi penelitian sebagaimana dijelaskan sebelumnya, hasil penelitian menunjukkan hubungan antara sosialisasi kebijakan, pengawasan wajib pajak, pemeriksaan pajak dan penagihan pajak terhadap kepatuhan wajib pajak dan penerimaan $\mathrm{PPh}$ Badan dengan kepatuhan wajib pajak sebagai variable perantara. Secara teoritis, hal ini dapat mendorong riset selanjutnya dapat memperbanyak variabel independen yang belum masuk dalam penelitian ini yang mempengaruhi kepatuhan dan penerimaan $\mathrm{PPh}$ Badan sehingga hasil dapat mencerminkan keseluruhan dari kondisi yang sebenarnya sedangkan dari sisi praktis diharapkan dapat memberikan sebuah masukan untuk Direktorat Jenderal Pajak dalam menyusun strategi terkait kegiatan yang dilakukan dalam menghimpun penerimaan negara mendaptkan hasil yang maksimal.

Keterbatasan penelitian ini antara lain dalam hal waktu pengumpulan data, jumlah populasi dan variabel yang digunakan dalam penelitian. Sehingga disarankan bagi peneliti selanjutnya untuk dapat menambah rentang waktu penelitian, menambah variabel penelitian yang terkait dengan kepatuhan wajib pajak dan penerimaan Pajak Penghasilan Badan serta memperluas objek penelitian seperti seluruh Kantor Pelayanan Pajak di lingkungan Kantor Wilayah DJP se-Jakarta.

\section{Daftar Pustaka}

Abercrombie, N., Hill, S., \& Turner, B. S. (2010). Kamus Sosiologi. Yogyakarta: Pustaka Pelajar.

Alfian, R. (2013). Pengaruh Kepatuhan Wajib Pajak Orang Pribadi Terhadap Penerimaan Pajak di KPP Pratama Surabaya Krembangan. Jurnal Akuntansi AKUNESA, 1(3).

Rizkilina, P. A., \& Pratomo, D. (2015). Pengaruh Pengawasan Dan Konsultasi Pajak Dan Pemeriksaan Pajak Terhadap Tingkat Kepatuhan Pajak Penghasilan Badan Tahun 2011-2013 (studi Kasus Pada
Kpp Madya Bandung). eProceedings of Management, 2(2).

Boediono, G. T., Sitawati, R., \& Harjanto, S. (2018). Analisis Pengaruh Sosialisasi Perpajakan Terhadap Kepatuhan Wajib Pajak Dengan Kesadaran Sebagai Variabel Mediasi. Jurnal Penelitan Ekonomi dan Bisnis, 3(1), 22-38.

Darmayani, D., \& Herianti, E. (2017). Pengaruh Tingkat Kepatuhan Wajib Pajak Badan Terhadap Peningkatan Penerimaan Pajak Penghasilan Dengan Penagihan Pajak Sebagai Variabel Moderating (Pada KPP Pratama Cilandak Jakarta Selatan). InFestasi (Jurnal Bisnis dan Akuntansi), 13(1), 275-284.

Febriyanti, I. (2013). Pengaruh Kewajiban Kepemilikan NPWP, Pemeriksaaan pajak dan Penagihan pajak terhadap Penerimaan Pajak (Pada kantor Pelayanan Pajak Pratama di Wilayah Jakarta Selatan).

Imam, G. (2013). Aplikasi Analisis Multivariate dengan Program IBM SPSS 21 Update PLS Regresi. Semarang. Badan Penerbit Universitas Diponegoro. ISBN, 979(015.1).

Horton, P. B., \& Hunt, C. L. (1987). Sosiologi, Jilid I, Terj. Aminudin Ram \& tita Sobari, Jakarta: Penerbit Erlangga.

Sofyan, A., \& Hasan, A. (2015). Pengaruh Ekstensifikasi Pajak, Kepatuhan Wajib Pajak, Pemeriksaan Pajak, Penagihan Pajak dan Surat Paksa Pajak terhadap Penerimaan Pajak Penghasilan Orang Pribadi di Kpp Pratama Solok (Doctoral dissertation, Riau University).

Mandagi, C., Sabijono, H., \& Tirayoh, V. (2014). Pengaruh Pemeriksaan Pajak Terhadap Tingkat Kepatuhan Wajib Pajak Badan Dalam Memenuhi Kewajiban Perpajakannya Pada KPP Pratama Manado. Jurnal EMBA: Jurnal Riset Ekonomi, Manajemen, Bisnis dan Akuntansi, 2(3).

Herryanto, M., \& Toly, A. A. (2013). Pengaruh kesadaran wajib pajak, kegiatan sosialisasi perpajakan, dan pemeriksaan pajak terhadap penerimaan pajak penghasilan di 
KPP Pratama Surabaya Sawahan. Tax \& Accounting Review, 1(1), 124.

Meiliawati, A. (2013). Pengaruh Pemeriksaan dan Penagihan Pajak Terhadap Penerimaan Pajak Pada KPP Pratama Kosambi. Ultimaccounting: Jurnal Ilmu Akuntansi, 5(1), 1-18.

Mohammad, I., Saerang, D. P. E., \& Pangerapan, S. (2017). Pengaruh Pemeriksaan Dan Penagihan Pajak Terhadap Penerimaan Pajak Pada Kantor Pelayanan Pajak Pratama Manado. Going Concern: Jurnal Riset Akuntansi, 12(2).

Indonesia, R. (2000). Undang-Undang No. 19 Tahun 2000 Tentang Penagihan Pajak dengan Surat Paksa.

Indonesia, R. Undang-Undang No. 28 Tahun 2007 tentang Ketentuan Umum perpajakan.

Indonesia, R. Undang-Undang No. 36 Tahun 2008 tentang Pajak Penghasilan.

Priantara, D. (2000). Pemeriksaan dan Penyidikan Pajak. Djambatan.

Rachmawati, A. N. D. (2014). Pengaruh Account Representative (AR) terhadap Kepatuhan Wajib Pajak (Studi Pada KPP Pratama Kepanjen). Jurnal mahasiswa Perpajakan, 2(1).

Rahayu, S. K. (2010). Perpajakan Indonesia: konsep dan aspek formal. Yogyakarta: Graha Ilmu.

Rahman, O., Ritonga, K., \& Rusli, R. (2017). Pengaruh Sosialisasi Pajak, Pemeriksaan Pajak dan Sunset Policy Jilid II terhadap Penerimaan Pajak Penghasilan Badan di Kpp Madya Pekanbaru (Doctoral dissertation, Riau University).

Rizkilina, P. A., \& Pratomo, D. (2015). Pengaruh Pengawasan Dan Konsultasi Pajak Dan Pemeriksaan Pajak Terhadap Tingkat Kepatuhan Pajak Penghasilan Badan Tahun 2011-2013 (studi Kasus Pada Kpp Madya Bandung). eProceedings of Management, 2(2).

Rosyidi, F. (2016). Pengaruh Penagihan Pajak Dengan Surat Teguran Dan Surat Paksa Terhadap Kepatuhan Wajib Pajak Di
Lingkungan Kanwil DJP Jawa Tengah I Dan Jawa Tengah II. Jurnal Akuntansi Indonesia, 3(1), 47-58.

Simamora, P., \& Suryaman, D. (2015). Pengaruh Tingkat Kepatuhan Wajib Pajak Orang Pribadi Terhadap Penerimaan Pajak Penghasilan Orang Pribadi Pada Kpp Pratama Cibinong. JIMFE (Jurnal Ilmiah Manajemen Fakultas Ekonomi), 1(1), 2531.

Sumarsan, T. (2017). Perpajakan Indonesia Edisi Kelima. Jakarta: Indeks.

RW, N. S., Bagianto, A., \& Yuniati, Y. (2018). Pengaruh Pemeriksaan Pajak terhadap Kepatuhan Wajib Pajak dan Dampaknya terhadap Efektivitas Penerimaan Pajak Penghasilan Badan. Jurnal Ilmiah MEA (Manajemen, Ekonomi, \& Akuntansi), 2(2), 115-143.

Wardani, D. K., \& Wati, E. (2018). Pengaruh Sosialisasi Perpajakan Terhadap Kepatuhan Wajib Pajak Dengan Pengetahuan Perpajakan Sebagai Variabel Intervening (Studi Pada Wajib Pajak Orang Pribadi di KPP Pratama Kebumen). Nominal: Barometer Riset Akuntansi dan Manajemen, 7(1), 33-54.

Widomoko, W., \& Nofryanti, N. (2017). Pengaruh Kualitas Pelayanan, Pengawasan dan Konsultasi oleh Account Representative (Ar) terhadap Kepatuhan Wajib Pajak (Studi Kasus pada Kpp Menteng Satu Jakarta Pusat). Jurnal Renaissance, 2(01), 132-146.

Wulandari, R. (2015). Faktor-Faktor Yang Mempengaruhi Penerimaan Pajak Penghasilan Pada KPP Pratama. Perbanas Review, 1(01).

Wulandari, T., Andreas, A., \& Ilham, E. (2015). Pengaruh Sosialisasi Perpajakan, Pengetahuan Perpajakan, Dan Kualitas Pelayanan Terhadap Kepatuhan Wajib Pajak Dengan Kesadaran Wajib Pajak Sebagai Variabel Intervening (Studi Pada Kantor Pelayanan Pajak Pratama Pekanbaru Senapelan) (Doctoral dissertation, Riau University).

Yeni, R. (2013). Pengaruh Tingkat Kepatuhan Wajib Pajak Badan Terhadap Peningkatan 
Wieldy Menanda, Darmansyah, JMV. Mulyadi, Nurmala Ahmar: Determinan Kepatuhan dan Penerimaan PPh Badan Pada Kantor Wilayah Direktorat Jenderal Pajak Jakarta Timur

Penerimaan Pajak Yang Dimoderasi Oleh Pemeriksaan Pajak Pada KPP Pratama Padang. Jurnal Akuntansi, 1(1). 